Journal of Agricultural Sciences
(Tarım Bilimleri Dergisi)

\title{
Effect on Yield and Some Quality Characteristics of Seed Harvest at Different Stages of Maturity in Nigella sativa $\mathbf{L}$.
}

\author{
Nimet KARA $^{a^{*}}(\mathbb{D})$, Gökhan GÜRBÜZER ${ }^{a}(\mathbb{D})$, Muhammed BIYIKLI ${ }^{\mathrm{a}}(\mathbb{D})$, Hasan BAYDAR ${ }^{\mathrm{a}}$ (D)

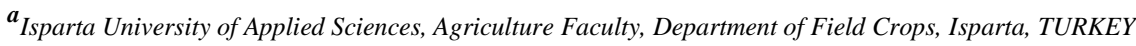 \\ ARTICLE INFO \\ Research Article \\ *Corresponding Author: Nimet KARA, E-mail: nimetkara@isparta.edu.tr \\ Received: 09 December 2019 / Revised: 01 June 2020 / Accepted: 03 June 2020 / Online: 04 September 2021
}

\section{ABSTRACT}

Nigella sativa L. is a significant medicinal and aromatic plant due to the usage of both its seed and fixed oil. The aim of the study is to investigate the effects on seed yield, various yield components, fixed and essential oil content, and chemical composition (2018 year) of black cumin when harvesting the seed at four different stages of maturity. These stages were $25 \%\left(\mathrm{SH}_{1}\right), 50 \%\left(\mathrm{SH}_{2}\right), 75 \%\left(\mathrm{SH}_{3}\right)$ and $100 \%\left(\mathrm{SH}_{4}\right)$ browning of capsules. Two-year field experiments (2017 and 2018) were set up according to a randomized complete block design with triplicate, using a black cumin population obtained from the Burdur province under Isparta ecological conditions.

Significant statistical differences were found among the harvest stages in regards to the seed yield, plant height and the thousand-seed weight, while no differences were found in the numbers of capsules and branches, essential oil and fixed oil contents in both experimental years. Seed yield and its components increased during the harvest stage up to $\mathrm{SH}_{3}$, while essential oil and fixed oil contents decreased insignificantly from $\mathrm{SH}_{1}$ to $\mathrm{SH}_{4}$ in both years. According to the combined years; plant height, the number of capsules, the number of branches, the 1000 seed weight, seed yields, essential oil and fixed oil contents varied between 38.3-42.5 cm, 6.03-6.85 capsule plant ${ }^{-1}, 6.50-6.91$ branches plant $^{-1}, 2.30-$ $2.57 \mathrm{~g}, 307.3-542.3 \mathrm{~kg} \mathrm{ha}{ }^{-1}, 0.087-0.101 \%$ and $31.14-32.69 \%$, respectively.

The main components of black cumin essential oil were characterized by cymol (25.01-26.90\%), thymoquinone $(2.39-4.41 \%)$, carvacrol (10.12-10.41\%), junipene (5.33-6.66\%), $\Delta$-3-carene $(5.55-8.71 \%), \beta-$ pinene (2.98-3.65), trans-sabinene hydrate (8.02-11.93\%) and $\alpha$-thujene (7.82-9.42\%) according to harvest stages in the 2018 season.

Considering the present results, $\mathrm{SH}_{3}$ stage was advised because of its higher seed yield. The contents of essential oil composition of black cumin varied according to harvest stages.

Keywords: Harvest stages, Seed yield, Thymoquinone, Essential oil composition

(C) Ankara University, Faculty of Agriculture

\section{Introduction}

Black cumin is an annual herbaceous plant which is grown widely in Southwest Asia, Europe and North Africa, and the Afyon, Isparta, Burdur and Konya provinces in Turkey (Baytop 1984). The species of Nigella sativa L., Nigella damascena L. and Nigella arvensis L. are traded and cultivated in Turkey because they are widely used in folk medicine and as a culinary spice (Kar et al. 2007). Black cumin is used in the food industry as an ingredient in food products, herbal teas and bakery products, and it is also used in the pharmaceutical, cosmetic and dyeing sectors (Baytop 1984). Nigella seeds contain protein, alkaloid, saponin, fixed and essential oil (Işık et al. 2017), crude fiber, minerals and vitamins (Güler et al. 2006).

Generally, black cumin has been grown based on natural precipitation (without watering) in continental climatic conditions. A higher seed yield can also be obtained under irrigated conditions. However, farmers prefer higher yielding plants such as fruits, vegetables, corn, potato, sugar beet etc. in irrigated conditions. In order to compete with these crops, it is of great importance to investigate the factors affecting the yield and quality characteristics of black cumin, one of these being harvest time. An early harvest of black cumin may cause a loss of yield due to non-uniform ripening, and a late harvest may cause-the seed spilling as a result of capsule dehiscence. In addition to the amount of thymoquinone, which is one of the main active compounds of black cumin, essential oil can also be influenced by the maturity stages. There are a few studies in which a proper harvest stage was determined for high seed yield and quality in non-uniform ripening plants such as black cumin. Özel (2008) stated that the yield and quality of anise were affected by the harvest stage, and the highest seed yield, essential oil and anethole were obtained from the primary umbel completely mature stage. Similarly, Omidbaigi et al. (2003) determined that anise harvested in different levels of maturation caused changes in the yield and the essential oil composition of the crop. Kara (2017) reported that the highest grain yield of buckwheat occurred when $80 \%$ of the grains had turned brown. There are some research findings indicating that the chemical composition of black cumin is affected by both genetic and environmental factors (Arslan et al. 2012; Ertaş 2016). 
The purpose of the present study was to investigate the effect of change on seed yield and yield components, fixed and essential oil contents and composition of black cumin when harvesting the seed at different stages of maturity.

\section{Material and Methods}

The experiment was carried out during the 2017 and 2018 years under the Isparta ecological conditions. From March to the end of August of 2017 and 2018, there was a total precipitation of 213.9 and $198.2 \mathrm{~mm}$ and an average temperature of 17.0 and $18.2^{\circ} \mathrm{C}($ Table 1$)$.

Table 1- Temperature and precipitation data of the experiment area*

\begin{tabular}{lllllllll}
\hline \multirow{2}{*}{ Climatic factors } & \multirow{2}{*}{ Years } & \multicolumn{3}{c}{ Months } & \multicolumn{2}{c}{$\begin{array}{c}\text { Total or } \\
\text { Average }\end{array}$} \\
\cline { 3 - 8 } & & March & April & May & June & July & August \\
Average & 2017 & 7.3 & 10.6 & 14.9 & 20.1 & 25.1 & 24.0 & 17.0 \\
Temperature $\left({ }^{\circ} \mathrm{C}\right)$ & 2018 & 9.2 & 14.8 & 16.8 & 20.3 & 24.3 & 24.1 & 18.2 \\
& Long Years & 9.3 & 10.8 & 15.6 & 20.1 & 23.4 & 25.8 & 17.5 \\
\hline \multirow{2}{*}{$\begin{array}{l}\text { Precipitation } \\
(\mathrm{mm})\end{array}$} & 2017 & 74.4 & 25.6 & 49.5 & 30.9 & 13.1 & 20.4 & 213.9 \\
& 2018 & 65.9 & 51.0 & 43.3 & 30.8 & 4.0 & 3.2 & 198.2 \\
\hline
\end{tabular}

*; Data were taken from Isparta Meteorological Station

In the years 2017 and 2018, the experimental soil had a sandy-loamy, low organic matter (1.75\% and $1.68 \%$, respectively), slightly alkaline (pH 7.86 and 7.51, respectively) and limy (15.47\% and $13.16 \% \mathrm{CaCO}_{3}$, respectively).

In this study, a local black cumin population, which is cultivated in the Burdur province, was used as genetic material. Harvest stages were arranged according to the randomized complete block design, with three replicates. Seeds were sown in $20 \mathrm{~cm} x$ $\mathrm{cm}$ on row spacing. Each plot area was $5 \mathrm{~m}^{2}(5.0 \mathrm{~m} \times 1.0 \mathrm{~m})$ and consisted of 5 rows. Seeds were sowed by hand at $1-2 \mathrm{~cm}$ depths using a dibbler in the first week of March in both experimental years. The total quantity of phosphorus with $46 \% \mathrm{P}_{2} \mathrm{O}_{5}$ and half of ammonium sulphate with $21 \% \mathrm{~N}$ fertilizers were applied at the time of sowing at a rate of $60 \mathrm{~kg} \mathrm{ha}^{-1}$ and $40 \mathrm{~kg} \mathrm{ha}^{-1}$, respectively, and the other half of ammonium sulphate was applied when the plant was at a height of 15-20 cm (Tunçtürk et al. 2012). The plants were non-irrigated at any growing periods, and all the cultural practices were applied in both years.

In order to determine the seed yield and quality properties of black cumin, the plants were harvested from 3 rows in the center of each plot at four different stages of seed maturity as follows; $\mathrm{SH}_{1}$ (Seed harvest): browning of $25 \%$ of capsules, $\mathrm{SH}_{2}$ : browning of $50 \%$ of capsules, $\mathrm{SH}_{3}$ : browning of $75 \%$ of capsules and $\mathrm{SH}_{4}$ : browning of $100 \%$ of capsules. After the harvest, the capsules were dried for one week on wire racks and the seeds in the dry capsules were then manually blended. Seed yield $\left(\mathrm{kg} \mathrm{ha}^{-1}\right), \mathrm{plant}$ height $(\mathrm{cm})$, the number of branches (branches plant $\left.{ }^{-1}\right)$, the number of capsules (capsule plant ${ }^{-1}$ ) and the 1000-seed weight $(\mathrm{g}$ ) were determined as described by Telci (1995).

For each of the harvest stages, $100 \mathrm{~g}$ of powdered black cumin samples in $0.5 \mathrm{~L}$ of water were hydro-distilled using Clevenger apparatus for 3 hours according to the standard procedure described in the European Pharmacopoeia for determining the essential oil content $(\mathrm{v} / \mathrm{w}, \%)$. The fixed oil content $(\%)$ of back cumin seeds belonging to each harvest stage were determined using $N M R$ (Nuclear Magnetic Resonance, Bruker mqone) apparatus. The measurement was conditioned for 30 minutes at $20{ }^{\circ} \mathrm{C}$ and $35{ }^{\circ} \mathrm{C}$ in NMR, and the results are presented as a percentage (\%). The chemical composition of the essential oil was identified by GC-MS (Gas Chromatography-Mass Spectrometry, Shimadzu 2010 Plus GC).

All the data were evaluated with analysis of variance (ANOVA) using an SAS Statistics Package Program. Means were compared using the LSD (Least Significant Difference) test.

\section{Results and Discussions}

\subsection{Seed yield and its components}

Significant statistical differences were found among the harvest stages of black cumin in relation to seed yield, plant height and the thousand-seed weight. However, no differences were found in the number of capsules, the number of branches, or the essential oil and fixed oil contents in either year or combined years (Table 2). Significant statistical differences (except for essential and fixed oil content) were found between the mean of the years. The plant height, number of capsules, number of branches and seed yield were higher in the first year, while the thousand-seed weight was higher in the second year. Essential oil and fixed contents were not changed significantly according to the mean the years. Differences in the yield and some yield components between the years might be due to higher raining during the growing period in the second year (Table 1). Sufficient moisture in the soil promotes the nutrition uptake of the plants, so rainfall in the first year increased the seed yield. Similar results that were obtained in other studies have also reported that seed yield and other plant characteristics varied depending on the climatic conditions of the year (Sadeghi et al. 2009; Ghamarnia \& Jalili, 2013; Kara et al. 2015). 
According to the combined years, the highest plant height $(43.1 \mathrm{~cm})$, number of branches $\left(6.91\right.$ branches plant $\left.^{-1}\right)$, number of capsules $\left(6.85\right.$ capsule plant $\left.^{-1}\right), 1000$ seed weight $(2.57 \mathrm{~g})$ and seed yield $\left(542.3 \mathrm{~kg} \mathrm{ha}^{-1}\right)$ were obtained from the $\mathrm{SH}_{3}$ stage. The lowest values of these characteristics were determined from the $\mathrm{SH}_{1}$ stage (Table 2). The plant height slightly increased by delaying the harvest stage, but there weren't significant statistical differences among $\mathrm{SH}_{2}, \mathrm{SH}_{3}$ and $\mathrm{SH}_{4}$. Similarly, there weren't significant differences between all harvest stages in the number of branches and capsules per plant in both years. These results can be explained by the determinate growth of black cumin, due to the ceasing of growth after the flowering stage. The 1000 seed weight decreased at the last harvest stage $\left(\mathrm{SH}_{4}\right)$. This could be as a result of the respiration losses which occurred in the seed storage. The reason for this is that when the plant reaches harvest maturity, the photosynthesis decreases, but respiration continues (Bugbee \& Salisbury 1988). The seed yield increased up to the $\mathrm{SH}_{3}$ stage, and it decreased in following harvest stage $\left(\mathrm{SH}_{4}\right)$. This decrease may have occurred due to the decrease of the 1000 seed weight at the $\mathrm{SH}_{4}($ Table 2). Özgüven \& Şekeroğlu (2007) and Sadeghi et al. (2009) informed that there was a positive relationship between seed yield and its such as the number of branches, number of capsules and the 1000 seed weight. In studies conducted on another plant by Özel (2008) and Kara (2017) they reported that seed yields of anise and buckwheat with non-uniform ripening increased up to a certain ripening stage, and then it decreased. In other studies that were conducted, black cumin seed yield varied between 367.8-527.3 kg ha-1 (Telci 1995), 166.7- 600.0 $\mathrm{kg} \mathrm{ha}^{-1}$ (Arslan et al. 2012), 676.6-903.3 kg ha-1 (Kulan et al. 2012) and 325.9-416.3 kg ha-1 (Seyyedan et al. 2014). In comparison with the above studies, the differences in seed yield could be as a result of a variety of characteristics, maturity periods of genotypes, climatic factors and agricultural practices (Karim et al. 2017; Selicioğlu 2018; Sultana et al. 2018).

Table 2- Effect on yield, some yield characteristics, essential oil and fixed oil content of seed harvest at different stages of maturity in black cumin

\begin{tabular}{|c|c|c|c|c|c|c|}
\hline \multirow[t]{2}{*}{ Harvest stages } & \multicolumn{3}{|c|}{ Plant height $(\mathrm{cm})$} & \multicolumn{3}{|c|}{ Number of branches (branches plant ${ }^{-1}$ ) } \\
\hline & 2017 & 2018 & Combined years & 2017 & 2018 & Combined years \\
\hline $\mathrm{SH}_{1}$ & $43.3 \mathrm{~b}$ & $33.4 \mathrm{~b}$ & $38.3 \mathrm{~b}$ & 6.96 & 6.03 & 6.50 \\
\hline $\mathrm{SH}_{2}$ & $48.1 \mathrm{a}$ & $33.5 \mathrm{~b}$ & $40.8 \mathrm{ab}$ & 6.80 & 6.30 & 6.55 \\
\hline $\mathrm{SH}_{3}$ & $48.4 \mathrm{a}$ & $34.8 \mathrm{a}$ & $41.6 \mathrm{a}$ & 7.26 & 6.56 & 6.91 \\
\hline $\mathrm{SH}_{4}$ & $49.8 \mathrm{a}$ & $35.4 \mathrm{a}$ & $42.5 \mathrm{a}$ & 7.20 & 6.35 & 6.76 \\
\hline LSD Harvet stages & 4.63 & 1.20 & 2.65 & - & - & - \\
\hline F value & $12.81 * *$ & $9.11 *$ & $20.90 * *$ & $0.52^{\mathrm{ns}}$ & $0.55^{\mathrm{ns}}$ & $0.88^{\mathrm{ns}}$ \\
\hline $\mathrm{CV}(\%)$ & 3.27 & 3.04 & 3.22 & 7.13 & 8.07 & 7.58 \\
\hline Years & $47.4 \mathrm{~A}$ & $34.2 \mathrm{~B}$ & LSD years: $2.17 * *$ & $7.05 \mathrm{~A}$ & $6.30 \mathrm{~B}$ & LSD years: $0.45^{*}$ \\
\hline \multirow[t]{2}{*}{ Harvest stages } & \multicolumn{3}{|c|}{ Number of capsule (capsule plant ${ }^{-1}$ ) } & \multicolumn{3}{|c|}{1000 seed weight $(g)$} \\
\hline & 2017 & 2018 & Combined years & 2017 & 2018 & Combined years \\
\hline $\mathrm{SH}_{1}$ & 6.70 & 5.63 & 6.16 & $2.20 \mathrm{~b}$ & $2.40 \mathrm{~b}$ & $2.30 \mathrm{~b}$ \\
\hline $\mathrm{SH}_{2}$ & 6.80 & 6.46 & 6.63 & $2.30 \mathrm{ab}$ & $2.50 \mathrm{ab}$ & $2.40 \mathrm{~b}$ \\
\hline $\mathrm{SH}_{3}$ & 7.13 & 6.56 & 6.85 & $2.48 \mathrm{a}$ & $2.66 \mathrm{a}$ & $2.57 \mathrm{a}$ \\
\hline $\mathrm{SH}_{4}$ & 6.70 & 5.36 & 6.03 & $2.43 \mathrm{ab}$ & $2.56 \mathrm{ab}$ & $2.45 \mathrm{ab}$ \\
\hline LSD Harvet stages & - & - & 0.55 & 0.261 & 0.252 & 0.158 \\
\hline F value & $1.63^{\mathrm{ns}}$ & $3.50^{\mathrm{ns}}$ & $2.62^{\mathrm{ns}}$ & $6.56 *$ & $5.56 *$ & $7.87 *$ \\
\hline $\mathrm{CV}(\%)$ & 4.07 & 7.21 & 6.82 & 3.81 & 3.32 & 3.56 \\
\hline Years & $6.83 \mathrm{~A}$ & $6.01 \mathrm{~B}$ & LSD years: $0.39^{*}$ & $2.35 \mathrm{~B}$ & $2.50 \mathrm{~A}$ & LSD $_{\text {years: }} 0.07 *$ \\
\hline \multirow[t]{2}{*}{ Harvest stages } & \multicolumn{3}{|c|}{ Seed yields $\left(\mathrm{kg} \mathrm{ha}^{-1}\right)$} & \multicolumn{3}{|c|}{ Essential oil content $(\%)$} \\
\hline & 2017 & 2018 & Combined years & 2017 & 2018 & Combined years \\
\hline $\mathrm{SH}_{1}$ & $311.7 \mathrm{c}$ & $303.2 \mathrm{c}$ & $307.3 \mathrm{~d}$ & 0.099 & 0.103 & 0.101 \\
\hline $\mathrm{SH}_{2}$ & $479.5 \mathrm{~b}$ & $451.0 \mathrm{~b}$ & $465.2 \mathrm{~b}$ & 0.096 & 0.102 & 0.099 \\
\hline $\mathrm{SH}_{3}$ & $564.9 \mathrm{a}$ & $519.8 \mathrm{a}$ & $542.3 \mathrm{a}$ & 0.088 & 0.096 & 0.092 \\
\hline $\mathrm{SH}_{4}$ & $441.6 \mathrm{~b}$ & $434.1 \mathrm{~b}$ & $437.8 \mathrm{c}$ & 0.085 & 0.089 & 0.087 \\
\hline LSD Harvet stages & 39.50 & 23.8 & 13.5 & - & - & - \\
\hline F value & $195.630 * *$ & $397.45 * *$ & $488.94 * *$ & $3.29^{\mathrm{ns}}$ & $2.12^{\mathrm{ns}}$ & $6.41^{\mathrm{ns}}$ \\
\hline $\mathrm{CV}(\%)$ & 4.90 & 3.84 & 2.45 & 5.44 & 6.27 & 5.59 \\
\hline Years & $449.4 \mathrm{~A}$ & $426.7 \mathrm{~B}$ & LSD $_{\text {years: }}$ 9.58* & 0.092 & 0.097 & LSD $_{\text {years: }}$ ns \\
\hline \multirow[t]{2}{*}{ Harvest stages } & \multicolumn{3}{|c|}{ Fixed oil content $(\%)$} & & & \\
\hline & 2017 & 2018 & Combined years & & & \\
\hline $\mathrm{SH}_{1}$ & 32.36 & 33.02 & 32.69 & & & \\
\hline $\mathrm{SH}_{2}$ & 31.38 & 33.71 & 32.54 & & & \\
\hline $\mathrm{SH}_{3}$ & 32.20 & 31.48 & 31.53 & & & \\
\hline $\mathrm{SH}_{4}$ & 30.81 & 30.87 & 31.14 & & & \\
\hline LSD ${ }_{\text {Harvet stages }}$ & - & - & - & & & \\
\hline F value & $2.67^{\mathrm{ns}}$ & $3.65^{\mathrm{ns}}$ & $2.32^{\mathrm{ns}}$ & & & \\
\hline $\mathrm{CV}(\%)$ & 2.50 & 2.98 & 2.75 & & & \\
\hline Years & 31.68 & 32.27 & LSD $_{\text {years: }} \mathrm{ns}$ & & & \\
\hline
\end{tabular}

$\mathrm{SH}$; Seed harvest, *, **; significant at $\mathrm{P}<0.05$ and $\mathrm{P}<0.01$ probability levels, respectively, ns; non significant 


\subsection{Essential oil and fixed oil content}

Considering the combined years in the present study, the essential oil and fixed oil content varied between $0.087-0.101 \%$ and 31.14-32.69\%, respectively. The essential oil and fixed oil content tended to decrease only slightly from $\mathrm{SH}_{1}$ to $\mathrm{SH}_{4}$ (Table 2). However, differences among in the harvest stages in both years weren't statistically significant.

El-Gamal \& Ahmed (2017) reported that the essential oil content of fennel slowly decreased depending on delaying harvest time in the seed maturity period, while it was higher in early harvest stages. Telci et al. (2009) stated that the essential oil content of fennel was higher in the early stages of fruit development than the advanced stages. However, in our study, seeds were harvested at different stages of maturity, therefore, the rate of decrease in essential oil content was lower. In the plants harvested of seed, the synthesis of essential oil and fixed oil can be completed when it reaches the stage of maturity. In comparison to previous studies, the essential oil content of the present results were lower than the values reported: 0.5\% (Bourgou et al. 2010), 0.5-1.6\% (Ramadan 2007), 0.27-0.35\% (Toncer \& K1z1l, 2004), while showing parallels with the findings of Benkaci et al. (2013) and Kara et al. (2015). Kara et al. (2015), Mohammadi et al. (2016) and Mazaheri et al. (2019) reported that fixed oil content varied between 26.0-32.5\%, 31.6-40.0\% and 34.0$39.0 \%$, respectively. These differences might have been due to air temperature, precipitation, soil fertility, agronomic conditions and harvest stages (Telci 1995; Kulan et al. 2012; Kara et al. 2015)

\subsection{Chemical composition of essential oil}

Essential oil compositions in black cumin oil were shown in Table 3. Cymol, thymoquinone, carvacrol, junipene, $\Delta$-3carene, $\beta$-pinene, trans-sabinene hydrate and $\alpha$-thujene were determined as the main components in the essential oil of black cumin. According to the harvest stages, the cymol, thymoquinone, carvacrol, junipene, $\Delta$-3-carene, $\beta$-pinene, trans-sabinene hydrate and $\alpha$-thujene varied between $25.01-26.90 \%, 2.39-4.41 \%, 10.12-10.41 \%, 5.33-6.66 \%, 5.55-$ $8.71 \%, 2.98-3.65,8.02-11.93 \%$ and $7.82-9.42 \%$, respectively. The rates of these components varied according to harvest stages. Generally, $\alpha$-thujene, $\alpha$-pinene, $\beta$-pinene, $\Delta$-3-carene, cyclopropane, 4 -terpineol and thymoquinone content decreased, while cymol, trans-sabinene hydrate, cyclohexen and carvacrol contents were increased by delaying harvest stages up to $\mathrm{SH}_{4}$.

These changes could be as a result of climatic (especially temperature) differences between each harvest s tage. The amount of temperature until the next harvest stage may affect the synthesis of essential oil composition. For example, there were about 26 days in the first year and 24 days in the second year between the first harvest and the last harvest. Synthesis of secondary metabolites in plants can be effected from biotic and abiotic factors as well as genetic traits (Telci et al. 2014). In comparison to previous studies, rates of main essential oil components varied: $42.4 \%$ thymoquinone and 10.3\% carvacrol (Mahmoudvand et al. 2014), 67.7\% thymoquinone, $8.4 \%$ carvacrol, $4.8 \%$ junipene, $2.3 \%$ p-cymen and 1.9\% 4-terpineol (Palabıyık \& Aytaç 2018). These differences might have been due to variety, various ecological conditions including air temperature, radiation, precipitation and soil fertility affecting the production of secondary metabolites of black cumin (Benkaci et al. 2007; Mahmoudvand et al. 2014; Kara et al. 2015). 
Table 3- Chemical composition contents in different harvest stage of black cumin

\begin{tabular}{|c|c|c|c|c|c|}
\hline \multirow{2}{*}{ Chemical components* } & \multirow[b]{2}{*}{$R I$} & \multicolumn{4}{|c|}{ Harvest stages (\%) } \\
\hline & & $\mathrm{SH}_{1}$ & $\mathrm{SH}_{2}$ & $\mathrm{SH}_{3}$ & $\mathrm{SH}_{4}$ \\
\hline$\alpha$-Thujene & 927 & 9.42 & 8.37 & 7.82 & 8.71 \\
\hline$\alpha$-Pinene & 933 & 3.37 & 2.73 & 3.58 & 2.09 \\
\hline 3-Hexanol (CAS) Hexan-3-ol & 948 & 0.03 & 0.03 & 1.68 & 0.13 \\
\hline 2-Pentanol, 4-methyl- (CAS) 4-Methyl-2-pentanol & 957 & - & - & 1.91 & - \\
\hline Sabinene & 981 & 1.29 & 1.40 & 1.42 & 1.47 \\
\hline$\beta$-Phellandrene & 991 & - & - & 1.69 & 1.55 \\
\hline$\beta$-Pinene & 997 & 3.65 & 3.60 & 3.06 & 2.98 \\
\hline Pyridinepropanoic acid, $\alpha$-methyl-.beta.-oxo-, thyl es & 998 & 0.03 & - & 0.12 & - \\
\hline$\alpha$-Terpinene & 1001 & 0.07 & 0.42 & 0.52 & 0.65 \\
\hline Cymol & 1025 & 25.62 & 25.01 & 26.90 & 26.70 \\
\hline Limonene & 1031 & 1.20 & 1.49 & 2.41 & 1.73 \\
\hline Eucalyptol (1,8-Cineole) & 1035 & 0.11 & 0.12 & 0.14 & 0.11 \\
\hline 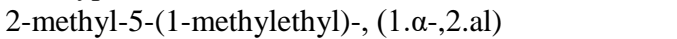 & 1041 & 0.06 & 1.36 & - & - \\
\hline$\gamma$-Terpinene & 1053 & 2.16 & 1.41 & 1.16 & 2.69 \\
\hline Linalool & 1062 & 0.58 & - & - & - \\
\hline$\Delta$-3-Carene & 1073 & 8.71 & 5.55 & - & - \\
\hline Trans-sabinene hydrate & 1100 & 9.15 & 8.02 & 10.85 & 11.93 \\
\hline Cyclopropane, 1,1-dimethyl-2-(3-methyl-1) & 1102 & - & 3.99 & 3.89 & 3.45 \\
\hline 4-Terpineol & 1190 & 3.93 & 3.06 & - & 2.19 \\
\hline Cyclohexen-1, 4-methyl-1-(1-methylethyl)- 4-Terp. & 1194 & - & - & 3.98 & 5.11 \\
\hline Benzeneethanol, $\alpha$-, $\alpha$-dimethyl acetate & 1198 & 0.12 & 0.13 & - & - \\
\hline Cis-p-Mentha-2,8-dien-1-ol & 1209 & 2.21 & 2.66 & - & 1.04 \\
\hline$\beta$-Cyclocitral & 1214 & - & - & 1.15 & - \\
\hline 2-Cyclohexen-1-one, 2-methyl-5-(1-methylethenyl) & 1255 & 0.21 & 2.44 & 2.15 & 4.26 \\
\hline Thymoquinone & 1261 & 4.41 & 2.70 & 2.82 & 2.39 \\
\hline Carvacrol & 1313 & 10.12 & 10.13 & 10.41 & 10.43 \\
\hline (1S,4R)-p-Mentha-2,8-diene, 1-hydroperoxide & 1326 & & 3.17 & - & - \\
\hline$\alpha$-Longipinene & 1361 & 0.73 & 0.86 & - & 1.07 \\
\hline Junipene & 1419 & 6.66 & 6.45 & 5.33 & 6.56 \\
\hline (-)-Caryophyllene oxide & 1749 & & 1.99 & - & - \\
\hline (-)-Caryophyllene oxide & 1982 & 1.16 & - & - & - \\
\hline Dimethoxy-Cis-9-Octadecene & 2113 & - & - & 2.37 & - \\
\hline
\end{tabular}

SH; Seed harvest, RI; Retention Indice, *; Contents of chemical compounds belong to 2018

\section{Conclusions}

As a results of the research: i) The $\mathrm{SH}_{3}$ harvest stage had the highest seed yield, with a mean of $542.3 \mathrm{~kg} \mathrm{~h}^{-1}$ so that in compared to the other harvest stages, it increased by 14.2-43.3\%. The yield and its components increased by delaying the harvest stage up to $\mathrm{SH}_{3}$, and decreased in the following harvest period $\left(\mathrm{SH}_{4}\right)$. Therefore, under Isparta's ecological conditions, black cumin should be harvested in the $\mathrm{SH}_{3}$ stage due to the higher seed yield.

ii) Differences among the harvest stages in relation to essential and fixed oil content in both years weren't statistically significant.

iii) Cymol, thymoquinone, carvacrol, junipene, $\Delta$-3-Carene, $\beta$-pinene, trans-sabinene hydrate and $\alpha$-thujene were identified as major compounds of black cumin's essential oil, and rates of these components varied according to the harvest stages.

\section{References}

Arslan Y, Katar D \& Subaşı İ (2012). Effect of different sowing dates in black cumin (Nigella sativa L.) on yield and some plant properties. Medicinal and Aromatic Plants Symposium, 13-15 September, Tokat, pp. 132-139 (in Turkish)

Baytop T (1984). Therapy with Medicinal Plants in Turkey. Publications of the Istanbul University No: 3255, p. 480, Istanbul (in Turkish)

Benkaci A F, Baaliouamer A, Meklati B Y \& Chemat F (2007). Chemical composition of seed essential oils from Algerian Nigella sativa extracted by microwave and hydrodistillation. Flavour Fragrance Journal 22: 148-153. DOI: 10.1002/ffj.1773

Bourgou S, Pichette A, Marzouk B \& Legault J (2010). Bioactivities of black cumin essential oil and its main terpenes from Tunisia. South African Journal of Botany 76: 210-216. DOI:10.1016/j.sajb.2009.10.009

Bugbee B G \& Salisbury F B (1988). Exploring the limits of crop productivity. Plant Physiology 88(3): 869-878. DOI: 10.1104/pp.88.3.869

Ertaş M E (2016). Determination of agrononmic and quality traits of black cumin genotypes (Nigella sp.) growing winter and summer planted in Tokat kazova conditions. Printed M.Sc. Thesis, Gaziosmanpaşa University Natural and Applied Sciences, p. 49, Tokat (in Turkish)

Ghamarnia H \& Jalili Z (2013). Water stress effects on different black cumin (Nigella sativa L.) components in a semi-arid region. International Journal of Agronomy and Plant Production 4(4): 753-762 
Güler T, Dalkılıç B, Ertas O N \& Çiftçi M (2006). The effect of dietary black cumin seeds (Nigella Sativa L.) on the performance of broilers. Asian-Austuralasian Journal of Animal Sciences 19(3): 425-430. DOI: 10.5713/ajas.2006.425

Işık S, Kartal M \& Erdem S A (2017). Quantitative analysis of thymoquinone in Nigella sativa L. (black cumin) seeds and commercial seed oils and seed oil capsules from Turkey. Ankara University Journal of Pharmacy Faculty 41(1): 34-41 DOI: 10.1501/Ecfak_0000000593

Kar Y, Sen N \& Tekeli Y (2007). Investigation of black cumin (Nigella sativa L.) seeds cultivated in region Samsun and country of Egypt in terms of antioxidant activity. Suleyman Demirel University Journal of Science 2(2): 197-203

Kara N, Katar D \& Baydar H (2015). Yield and quality of black cumin (Nigella sativa L.) Populations: The effect of ecological conditions. Turkish Journal of Field Crops 20(1): 9-14 DOI: 10.17557/.23190

Kara N (2017). The effect on grain yield and its nutrition content of harvest at different stages of seed maturity in buckwheat. Fresenius Environmental Bulletin 26 (12): 7451-7457

Karim M, Himel R M, Ferdush J \& Zakaria M (2017). Effect of irrigation levels on yield performance of black cumin. International Journal of Environment, Agriculture and Biotechnology 2(2): 960-966 DOI: 10.22161/ijeab/2.2.52

Kulan E G, Turan Y S, Gülmezoğlu N, Kara İ \& Aytaç Z (2012). Some agronomic and quality characteristics of black cumin (Nigella sativa L.) grown in semiarid conditions. Medicinal and Aromatic Plants Symposium, 13-15 September, Tokat, pp.177-181, (in Turkish)

Mahmoudvand H, Sepahvand A, Jahanbakhsh S, Ezatpour B \& Ayatollahi M S A (2014). Evaluation of antifungal activities of the essential oil and various extracts of Nigella Sativa and its main component, thymoquinone against pathogenic dermatophyte strains. Journal de Mycologie Médicale 24: 155-161 DOI: 10.1016/j.mycmed.2014.06.048

Mazaheri Y, Torbati M, Azadmard D S \& Savage G P (2019). A comprehensive review of the physicochemical, quality and nutritional properties of Nigella sativa oil. Food Reviews International 35(4): 342-362 DOI: 10.1080/87559129.2018.1563793

Mohammadi K S, Rahimi A \& Zartoshti M R (2016). The effect of micronutrients (Fe, Zn, B, and Mn) applied to the leaf on oil content and fatty acid composition of black cumin (Nigella sativa L.) in winter sowing condition. ÇOMU Journal of Agriculture Faculty 4(2): 87-93

Omidbaigi R, Hadjiakhoondi A \& Saharkhiz M (2003). Changes in content and chemical composition of Pimpinella anisum at various harvest time. Journal of Essential Oil-Bearing Plants 6: 46-50 DOI: 10.1080/0972-060X.2003.10643328

Özel A (2008). Anise (Pimpinella anisum): Changes in yields and component composition on harvesting at different stages of plant maturity. Explanation Agriculture 45: 117-126 DOI: 10.1017/S0014479708006959

Özgüven M \& Şekeroğlu N (2007). Agricultural practices for high yield and quality of black cumin (Nigella sativa L.) cultivated in Turkey. Acta Horticulturae 756: 329-337 DOI: 10.17660/ActaHortic.2007.756.35

Palabıyık G A \& Aytaç Z (2018). Chemical composition of the fixed and essential oils of Nigella sativa L. from Turkey. Current Perspectives on Medicinal \& Aromatic Plants 1: 19-27

Ramadan M F (2007) Nutritional value, functional properties and nutraceutical applications of black cumin (Nigella sativa L.) oilseeds: An overview. International Journal of Food Science and Technology 42: 1208-1218 DOI: 10.1111/j.1365-2621.2006.01417.x

Sadeghi S, Rahnavard A \& Ashrafi Z Y (2009). Study importance of sowing date and plant density affect on black cumin yield. Botany Research International 2(2): 94-98

El-Gamal S \& Ahmed H (2017). Influence of different maturity stages on fruit yield and essential oil content of some Apiaceae family plants B: Fennel (Foeniculum vulgare Mill.). Journal of Plant Production 8(1): 127-133 DOI:10.21608/jpp.2017.37825

Selicioğlu M (2018). Determination of agronomical and quality characters of some black cumin (Nigella sp.) populations in Kirsehir ecological conditions. Printed M.Sc. Thesis, Suleyman Demirel University Graduate School of Natural and Applied Sciences Department of Field Crops, p. 36, Isparta (in Turkish)

Seyyedan P, Daneshian J, Mirza M, Maleki A \& Alireza S (2014). The effect of nitrogen chemical fertilizer and zinc sulfate application on yield and its components of Nigella sativa L. under different humidity conditions. Bulletin Environmet Pharmacology Life Science 3(2): 92-99

Sultana S, Das B, Rudra B C, Das G \& Alam M B (2018). Effect of date of sowing on productivity of black cumin. International Journal of Current Microbiology Applied Science 7(1): 1796-1800 DOI: 10.20546/ijcmas.2018.701.217

Telci İ (1995). Effect on yield, yield components and some plant traits of black cumin (Nigella sativa L.) of different sowing rate in Tokat conditions. Printed M.Sc. Thesis, Gaziosmanpaşa University Natural and Applied Sciences, p. 37, Tokat (in Turkish)

Telci İ, Demirtas İ \& Sahin A (2009). Variation in plant properties and essential oil composition of sweet fennel (Foeniculum vulgare Mill.) fruits during stages of maturity. Industrial Crops and Products 30: 126-130 DOI: 10.1016/j.indcrop.2009.02.010

Telci İ, Yağlioğlu A S, Eser F, Aksit H, Demirtaş İ \& Tekin S (2014). Comparison of seed oil composition of Nigella sativa L. and N. damascena L. during seed maturation stages. Journal of the American Oil Chemists Society 91: 1723-1729 DOI: 10.1007/s11746-0142513-3

Toncer O \& Kizıl S (2004). Effect of seed rate on agronomic and technologic characters of Nigella sativa L. International Journal of Agriculture \& Biology 3: 529-532

Tunçtürk R, Tunçtürk M \& Çiftçi V (2012). The effects of varying nitrogen doses on yield and some yield components of black cumin (Nigella sativa L.). Advances in Environmental Biology 6(2): 855-858

(C) 2021 by the authors. Licensee Ankara University, Faculty of Agriculture, Ankara, Turkey. This article is an open access article distributed under the terms and conditions of the Creative Commons Attribution (CC BY) license (http://creativecommons.org/licenses/by/4.0/). 